Senko A.,
Kupin A.,
Mysko B.

\title{
DEVELOPMENT OF CLASSIFICATION MODEL BASED ON NEURAL NETWORKS FOR THE PROCESS OF IRON ORE BENEFICIATION
}

Об’єктом дослідження є прочеси збагачення залізорудної сировини в умовах гірничо-збагачувального комбінату. Фабрика по збагаченню залізних руд є рядом паралельно діючих технологічних ліній або секцій збагачення. Однією з ключових характеристик, що визначають режим роботи подрібнюючого апарату, являється подрібнюваність руди, прямо пов'язана з ї мічністю. Але на відміну від інших параметрів є проблема із постійним відстеженням значення мічності. Визначення даного параметру потребує лабораторного дослідження технологічної проби руди з конвеєра секцї̈ збагачення. Специфіка умов роботи секиї збагачення ускладнює відстеження параметру мічності шляхом встановлення апаратного датчика безпосередньо на конвеєрі. Тому було запропоновано визначати ї̈ шляхом прогнозування. Спираючись на інформачійні технологї Big Data, використовуючи накопичені статистичні дані, можна робити прогноз даних на проміжках між технологічними пробами.

Системно проаналізовано технологічний процес збагачення руди в умовах гірничозбагачувального комбінату. Представлена узагальнена структура моделі класифікацї, що, спираючись на накопичені статистичні дані секцї збагачення на основі поточних параметрів роботи секцї, здатна визначати параметри вхідної сировини. Визначення невідомого параметру відбувається за допомогою нейронної мережі зустрічного розповсюдження, в якій об’єднані такі алгоритми: самоорганізуюча карта Кохонена та зірка Гроссберга. Їх об’єднання призводить до зростання узагальнюючих властивостей мережі. Навчальна вибірка формується в результаті кластеризацї статистичних даних секцї̈ збагачення та вибору кластеру, до якого належить поточний стан робот секцї.

Представлений алгоритм прогнозування, заснований на поєднанні методів кластеризащї та використанні прогнозуючої нейромережі, дає можливість фахівщеві більш оперативно отримати рекомендаціі щодо прийняття рішень відносно поведінки об'єкту у порівнянні із отриманням даних лабораторного дослідження проби.

Ключові слова: модель класифікацї, система комп'ютерної підтримки рішень, нейронна мережа, збагачення руди, кластеризація статистичних даних.

Received date: 05.11.2018

Accepted date: 19.11 .2018

Published date: 30.06 .2019
Copyright (C) 2019, Senko A., Kupin A., Mysko B. This is an open access article under the CC BY license (http://creativecommons.org/licenses/by/4.0)

\section{Introduction}

In modern conditions, the task of improving the quality of the final product - concentrate - and reducing its cost is of particular importance, since the average quality of the products of mining and processing plants (MPP), which is $64-66 \%$, is lower among potential competitors (Russia, Sweden, Brazil) - $70 \%$ [1]. At the same time, the cost and the share of harmful impurities in concentrates of Ukrainian production, as a rule, are higher.

The deviation of the concentrate quality from the planned indicators is in the range of $-3 \ldots+2 \%$. Among the reasons for such fluctuations in work, the following were first identified: a change in the mineral composition of the ore being processed, a change in the operating modes of the technological equipment of the crushing department. Of particular importance is the stabilization of the quality parameters of the ore fed for processing, provided by the complex geological conditions of Ukrainian mining and processing plants, characterized by a variety of mineral varieties of ores and a significant range of useful component content in them [2]. In the ore supplied forbeneficiation, the average number of mineral varieties is $5-8$, and the range of the total and magnetic iron contents, for example, under the conditions of PJSC Southern Mining Factory (Kryvyi Rih, Ukraine), reaches $6 \%$ and $10 \%$, respectively. At the same time, the modern mining system does not allow a sufficiently long time to mine the same type of ore, which leads to instability of the mineral composition of the raw materials that are received for processing. During the work shift, the range of the content of the useful component in the initial ore reaches an average of $7-9$ abs. $\%$.

One of the key characteristics that determine the operating mode of the grinding apparatus is ore crushing, directly related to its strength [3]. But unlike other parameters, the problem is with constant monitoring of the strength value. The determination of this parameter requires a laboratory study of the technological ore sample from the conveyor of the beneficiation section. Changes in the 
indicators between sampling adversely affect further process control due to inadequate input data.

Therefore, it is relevant to study alternative methods for determining ore strength. In particular, forecasting this parameter using a classification model for the beneficiation process.

\section{The object of research and its technological audit}

The object of research is the processes of iron ore beneficiation in the conditions of a mining and processing plant.

Iron ore beneficiation factory near parallel to existing production lines or concentration sections. The technological line of magnetic ore beneficiation can be divided into a number of series-connected technological complexes, each of which includes technological operations: grinding, classification and magnetic separation. Grinding ore can be carried out in ball and non-ball mills.

The specifics of the working conditions of the beneficiation section complicate the monitoring of the strength parameter by installing a hardware sensor directly on the conveyor. Therefore, it is proposed to determine it by forecasting. Relying on Big Data information technologies, using the accumulated statistical data, it is possible to forecast data on the intervals between technological samples.

\section{The aim and objectives of research}

The aim of research is in creation of a classifying model for indirectly determining the input parameters of the beneficiation section using intelligent decision-making technology. This will improve the efficiency of the iron ore beneficiation process. To achieve this aim, it is necessary to complete the following objectives:

1. To formulate the general goal of constructing a classifying model of indirect determination of the input parameters of the beneficiation section.

2. To reveal individual blocks and general concepts of the functioning of the proposed model.

3. To provide a formalized description of the relationships between the individual elements of the model.

\section{Research of existing solutions of the problem}

The mineral processing manufacturing process is a typical complex industrial process. It consists of several processes connected in series, where the outputs of each individual process are inputs for the subsequent [4].

The functioning of each unit contains a system of operational optimization of the highest level, keeps performance indicators within the target ranges [5, 6].

The use of optical cameras with a resolution of up to $0.1 \mathrm{~mm}$ to determine the properties of raw materials requires their preliminary cleaning [7].

$\mathrm{X}$-ray radiometric methods for controlling the quality of lump ore, among the drawbacks, are insufficient radiation penetration depth [2].

The main limitation of systems based on X-ray fluorescence is that they are not able to quantify the elements that emit light [8].

Infrared thermography does not allow working with black materials; infrared radiation is poorly reflected [9].
Particles of raw materials that have a low metal content can't be detected by electromagnetic sensors [10]. To identify such raw materials, it is necessary to install additional measuring instruments.

Ultrasonic sensors [11] make it possible to identify up to five size classes of raw materials in suspensions, which are $60 \%$ solids.

In addition to analyzing the flow of raw materials, a whole range of methods is available that require systematic or automatic sampling [12]. Their disadvantage is a large delay in time (from several hours to several days).

The methods discussed above do not allow obtaining information about the raw materials entering the beneficiation section for the operational control of the technological process. It is proposed to develop a model that allows forecasting unknown data based on previously accumulated statistics.

\section{Methods of research}

In the study, the following scientific methods are used: - analysis method - when studying problems, questions and statements of individual research tasks; - method of generalization, abstraction and explanation - for the disclosure of the classifying model and the relationships between its individual blocks;

- method of mathematical analysis and optimization to determine the analytical formalization and description of the classifying model.

\section{Research results}

The performance of ball mills depends on many factors. The author of [13] introduced three series of factors. The first row is created by factors, determined by the crushed material: the size of the initial ore, the size of the crushed material, crushing of the ore. The second row contains factors that depend on the mill itself: the design of the ball mill, its size, and the shape of the lining. The third row is represented by factors that take into account the operating conditions of the technological unit:

- open or closed loop;

- efficiency of the classifying apparatus;

- degree of filling of the mill with grinding media;

- characteristic size;

- shape;

- density;

- hardness of grinding bodies;

- dilution of the pulp in the mill;

- the number of revolutions of the drum.

In the process of systematic research of a ball mill as a controlled object by the productivity channel, its model is obtained as a controlled object (Fig. 1).

Analysis of factors presented in Fig. 1 shows that they can be represented as process parameters that are being optimized. In this case, the input, output, disturbing and control parameters are usually distinguished by the content.

Technical and mineralogical varieties of ores of the PJSC Southern Mining Factory according to the strength indicator on the scale of prof. M. Protodyakonov vary mainly within 6-9 points. The general tendency toward a decrease in the strength of samples with an increase in their size is explained by the presence of large and small cracks in them, the number of which decreases with decreasing particle size. 


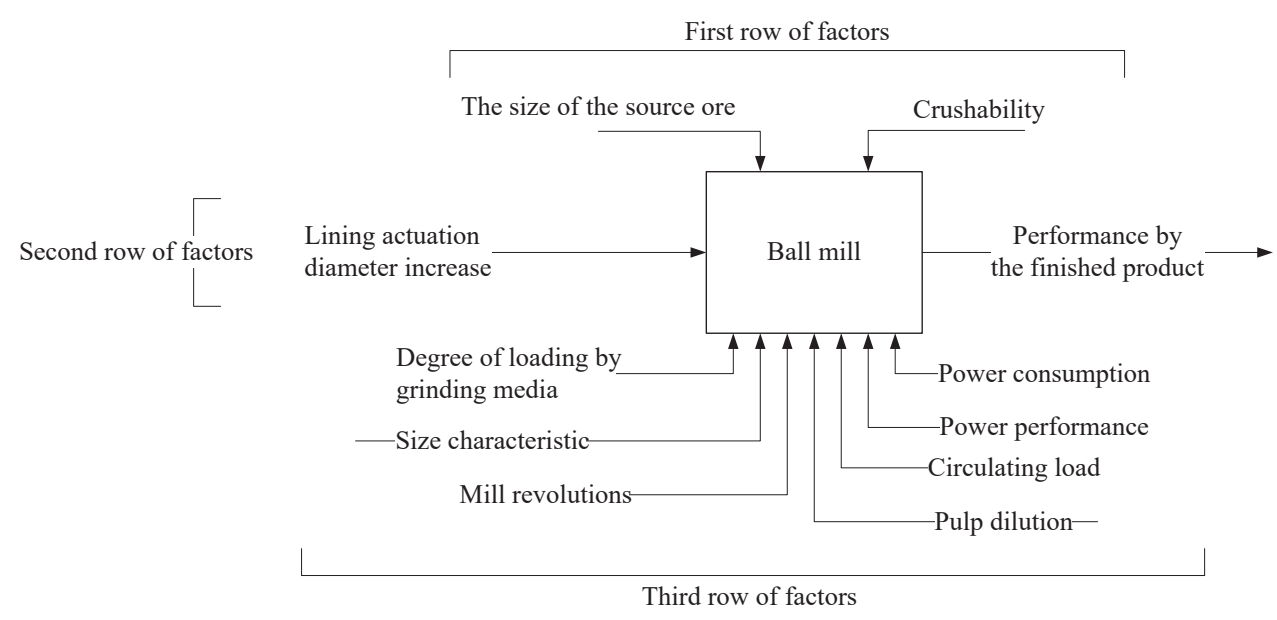

Fig. 1. Model of a ball mill as a controlled object

Based on the described technological process, the general structure of the predictive model can be divided into several blocks (Fig. 2).

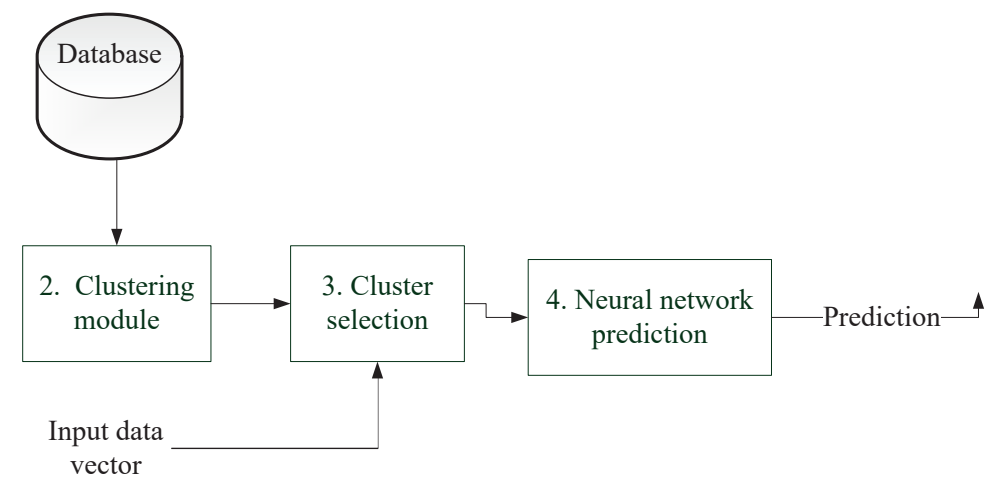

Fig. 2. The general structure of the predictive model
Each of the objects is characterized by a set of parameters:
Each variable $x k(i=\{a, s, d, i\})$ can take values from some set:

$$
x k=\{v k 1, v k 2, \ldots\} .
$$

The task of clustering is in building a set:

$$
C=\{c 1, c 2, \ldots, c k, \ldots, c g\},
$$

where $c k$ - a cluster containing objects from the set $I$ that are «similar» to each other:

$$
c k=\{i j, i k \mid i j \text { is } I, i k \text { is } I \text { and } d(i j, i k)<\sigma\},
$$

The first block is a database (DB) containing the accumulated data on the statistics of the beneficiation section for the previous period of operation. Indicators obtained from installed sensors for monitoring the operation of the section and laboratory data for the analysis of raw materials and products of the section.

The purpose of the technological database management system is the accumulation, backup and storage of information about the dynamics of the process parameters [10]. To implement as a result of the analysis of alternative options (Oracle, Firebird, Interbase, Sybase Adaptive Server Enterprise, MySQL), the industrial database management system (DBMS) MS SQL Server was chosen.

Clustering module. Formally, the task of clustering the statistical data of the beneficiation section can be described as follows. Given a lot of data objects $I$ (statistics of the state of the section), each of which is characterized by a set of attributes. It is necessary to construct a set of clusters $C$ and a mapping $F$ of the set $I$ onto the set $C$, i. e. $F: I \rightarrow C$. The mapping $F$ defines the data model and is the solution to the problem. The set $I$ is defined as follows:

$$
I=\{i 1, i 2, \ldots, i j\}
$$

where $i j$ - the investigated object. where $\sigma-$ a value that determines the proximity degree for including objects in one cluster; $d(i j, i k)$ - a proximity measure between objects, which is a distance.

An integral value of $d(i j, i k)$ is called the distance between the elements $i j$ and $i k$, if the following conditions are true:

1) $d(i j, i k) \geq 0$, for all $i j$ та $i k$;

2) $d(i j, i k)=0$, if and only if, when $i j=i k$;

3) $d(i j, i k)=d(i k, i j)$

4) $d(i j, i k) \leq d(i k, i m)+d(i m, i k)$.

If the distance $d(i k, i k)$ is less than some $\sigma$, then it is possible to say that the elements are close and move to the same cluster. Otherwise, it is believed that the elements are different from each other and they are moved to different clusters. The distances between the objects suggest their representation in the form of points $m$ of the multidimensional space $R m$ (in the case under consideration, $m=4$ ). As a measure, the Euclidean distance can be used. This distance is calculated as follows:

$$
d(i j, i k)=\sqrt{\sum_{t=1}^{m}\left(x_{j t}-x_{k t}\right)^{2}} .
$$

To give more weight to objects that are more distant from each other, the standard Euclidean distance rises to the square. 
To solve the clustering task, the Microsoft Analysis Services package was used, which is part of the Microsoft SQL Server database management system. And also, which allows to store data and perform business analysis at the expense of working with OLAP (OnLine Analytical Processing) and data mining. The package implements the Microsoft Clustering method, which is based on two principal clustering methods: the $k$-means algorithm (K-Means) and the EM algorithm (Expectation Maximization). Both algorithms belong to the class of so-called non-hierarchical algorithms based on the optimization of some objective function that determines the optimal partition of the data set into groups. The first method, the $k$-means method, is the hard clustering method. This means that a data point can belong to only one cluster and one probability value is calculated for each data point in this cluster to belong. The second method, Expectation Maximization (EM), is a soft clustering method. This means that a data point always refers to several clusters and the probabilities are calculated for all possible combinations of data points with clusters.

The third block selects from the clusters obtained at the previous stage the data set that will be used for learning the neural network. As a selection criterion, the vector of input parameters of the module belongs to one of the obtained clusters. The minimum distance to the center of the cluster by formula (1) determines this affiliation.

In the fourth block, the unknown state parameter of the beneficiation section is predicted. First, the neural network is learned. As a sample for learning, the statistics of the beneficiation section of the cluster selected at the previous stage are used. After learning, the parameters of the current state of operation of the beneficiation section are fed to the input of the neural network. As a result of forecasting at the output of the network, the value of the unknown parameter of the beneficiation section will be obtained.

In the framework of the study, the counterpropagating neural networks have the greatest prospect (Fig. 3). Networks of this type have less learning time than backpropagation networks. Therefore, such a network will promptly respond to changes in the conditions of the beneficiation process associated with fluctuations in the characteristics of the feedstock. The following algorithms are combined in a counterpropagation neural network: a self-organizing Kohonen map and a Grossberg star. Their combination leads to an increase in the generalizing properties of the network [14].

The created model is represented by the standard three-level (0-2) counterpropagating neural network. Layer 0 neurons serve as branch points and do not participate in calculations. Each neuron of layer 0 is associated with each neuron of layer 1 (Kohonen layer). Layer 1 and 2 neurons are similarly connected. The output of each layer neuron is the sum of the weighted inputs. As a result of a comparative assessment of the weighted sums of inputs of Kohonen neurons, a «winner» is determined a neuron for which this value is maximum. The output of this neuron will be assigned the value 1 , and the other neurons of the Kohonen layer - 0 . The Kohonen layer classifies input vectors into similar groups [15]. This provides a reflection of the multidimensional space of entrances to a neighborhood of the same point in the space of exits.

An input star-shaped neuron has $\mathrm{n}$ inputs that correspond to weighting factors $W=(w 1, w 2, \ldots, w n)$, one output $Y$ is the weighted sum of these inputs. Thus, the star is a detector of the state of the inputs and only responds to its input vector.

Adjustment of the scales is carried out according to the formula:

$$
W i(t+1)=W i(t)+\mu \cdot(X i-W i(t)),
$$

where $W i(t)$ - the weight vector of the $i$-th input star at the $t$-th learning cycle; $\mu$ - learning speed (selected at the beginning of $0.1-0.2$ and then gradually decreases); $X i$ - the input vector.

Grossberg output star performs the opposite function when a signal arrives at the input, a certain vector is issued. A neuron of this type has one input and $\mathrm{m}$ outputs with weights $W=(w 1, w 2, \ldots, w n)$, which are adjusted according to the formula:

$$
W i(t+1)=W i(t)+\alpha^{\prime} \cdot(Y i-W i(t))
$$

where $W i(t)$ - the weight vector of the $i$-th source star on the $t$-th learning cycle; $Y i$ - the output vector; $\alpha^{\prime}-$ learning speed. It is recommended to start learning with and gradually decrease to 0 .

The use of a neural network model involves an a priori classification of system states (beneficiation process) into a finite number of options [16, 17]. Each state is associated with a set of corrective actions that provide for specific changes in control parameters. The value of the output vectors $Y$ is used as the main classification criterion. To determine the current state of the process, the output of the neural network model is compared with the vector systems stored in the information database that determine the state of the beneficiation process.

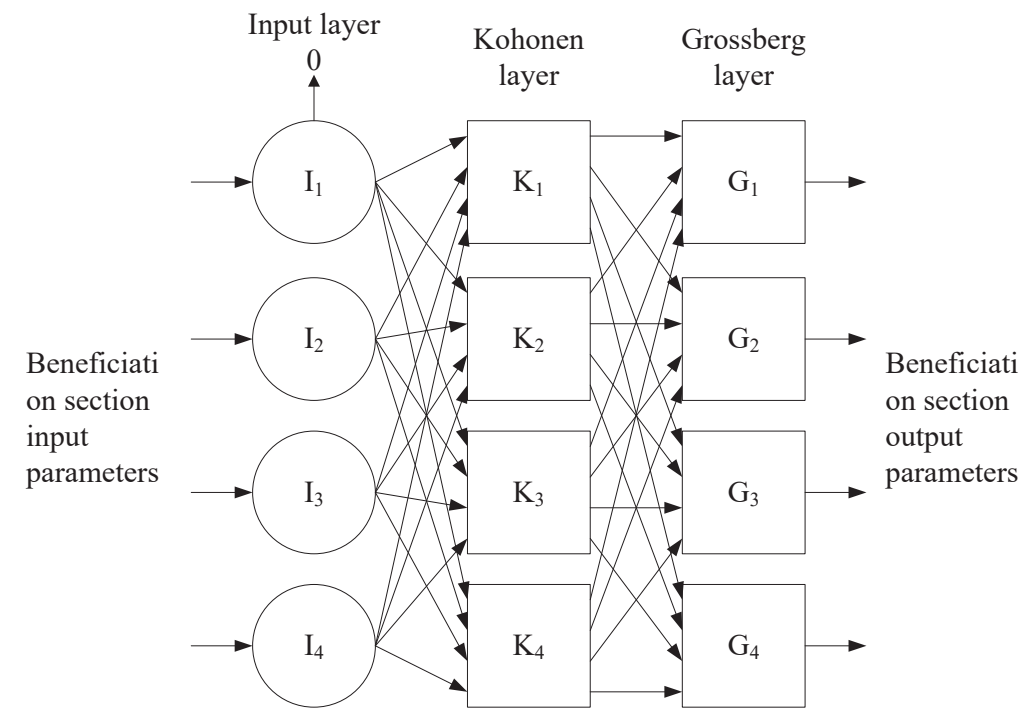

Fig. 3. Network with counter recognition without feedback 


\section{SWOT analysis of research results}

Strengths. A conceptual integrated classification model has been developed for indirectly determining the input parameters of the beneficiation section. The relationships between the individual elements of the constructed model are identified and disclosed. This allows to more quickly determine the characteristics of the raw materials supplied to the input of the beneficiation section and, responding to their changes, select the optimal operating modes of the section.

Compared with similar developments, this allows to obtain data on input raw materials without placing additional expensive sensors on the input conveyor of the section.

Weaknesses. The weak side can be considered that for learning a neural network requires the accumulation of a certain amount of statistical data on the operation of the beneficiation section. This makes it difficult to use this model for new equipment.

Opportunities. The use of a computer support system for solutions based on the proposed model can increase the efficiency of obtaining input data up to 24 times.

Threats. With the appearance of beneficiation complexes, including measuring equipment for determining the characteristics of raw materials at the inlet of the beneficiation section, the need for the application of the proposed model disappears.

\section{Conclusions}

1. It is shown that the main purpose of the classifying model of indirectly determining the input parameters of the beneficiation section is in obtaining data on input raw materials based on information about the current state of operation of the beneficiation section. This is done on the basis of a generalized analysis on the coverage of the proposed issues, the problem is in similar existing studies and taking into account the stated general goal of constructing such a model.

2. To achieve the main goal of constructing a classifying model, the main blocks of its construction are identified and disclosed, in particular:

- «Database»;

- «Clustering module»;

- «Cluster selection»;

- «Neural network prediction».

3. A formalized description of the relationships between the individual elements of the model is proposed. The combination of clustering methods reduces the load on the hardware because the scalable maximize wait method uses a local buffer. And iterations with viewing all the data work faster and this algorithm uses the processor cache much better than the unscaled method of maximizing the wait. The presented forecasting algorithm, based on a combination of clustering methods and the use of a predictive neural network, allows the specialist to more quickly receive recommendations for making decisions regarding the behavior of the object compared to obtaining laboratory test data.

\section{References}

1. Kupin, A. I. (2009). Uzghodzhene intelektualne keruvannia stadiyamy tekhnolohichnoho protsesu zbahachennia mahnetytovykh kvartsytiv v umovakh nevyznachenosti. Kryvyi Rih: Kryvorizkyi natsionalnyi universytet, 926.
2. Goncharov, Yu. G., Davidkovich, Yu. G., Geyzenblazen, B. E. (1968). Avtomaticheskiy kontrol' i regulirovanie tehnologicheskih protsessov na zhelezorudnyh obogatitel'nyh fabrikah. Moscow: Nedra, 277.

3. Skorohodov, V. F., Hohulya, M. S., Biryukov, V. V. (2010). Sozdanie ehffektivnyh tehnologiy i tehniki obogashcheniya mineral'nogo syr'ya s primeneniem metodov vychislitel'noy gidrodinamiki. Gorniy zhurnal, 12, 79-84.

4. Ding, J., Chai, T., Wang, H. (2011). Offline Modeling for Product Quality Prediction of Mineral Processing Using Modeling Error PDF Shaping and Entropy Minimization. IEEE Transactions on Neural Networks, 22 (3), 408-419. doi: https://doi.org/ $10.1109 / \operatorname{tnn} .2010 .2102362$

5. Jäschke, J., Skogestad, S. (2011). NCO tracking and selfoptimizing control in the context of real-time optimization. Journal of Process Control, 21 (10), 1407-1416. doi: https:// doi.org/10.1016/j.jprocont.2011.07.001

6. Würth, L., Hannemann, R., Marquardt, W. (2011). A twolayer architecture for economically optimal process control and operation. Journal of Process Control, 21 (3), 311-321. doi: https://doi.org/10.1016/j.jprocont.2010.12.008

7. Lu, L. (2015). Iron Ore. Mineralogy, Processing and Environmental Sustainability. Elsevier, 666. doi: https://doi.org/10.1016/ c2013-0-16476-8

8. Wills, B. A., Napier-Munn, T. (2006). Wills' Mineral Processing Technology. Elsevier, 456. doi: https://doi.org/10.1016/b9780-7506-4450-1.x5000-0

9. Ghosh, A., Sharma, A. K., Nayak, B., Sagar, S. P. (2014). Infrared thermography: An approach for iron ore gradation. $M i$ nerals Engineering, 62, 85-90. doi: https://doi.org/10.1016/ j.mineng.2013.12.002

10. Nevedrov, A. S., Oleynik, A. G. (2011). Ob instrumental'nyh sredstvah opredeleniya ehffektivnyh rezhimov obogashcheniya mineral'nyh rud. Informatsionnye resursy Rossii, 5, 35-38.

11. Morkun, V., Tron, V. (2014). Automation of iron ore raw materials beneficiation with the operational recognition of its varieties in process streams. Metallurgical and Mining Industry, 6, 4-7.

12. Hart, J. R., Zhu, Y., Pirard, E. (2011). Particle size and shape characterization: current technology and practice. Advances in the Characterization of Industrial Minerals, 77-127. doi: https:// doi.org/10.1180/emu-notes.2010.emu9-4

13. Andreev, S. E., Perov, V. A., Zverevich, V. V. (1980). Droblenie, izmel'chenie $i$ grohochenie poleznyh iskopaemyh. Moscow: Nedra, 415 .

14. Werbos, P. J. (1989). Backpropagation and neurocontrol: a review and prospectus. International Joint Conference on Neural Networks. doi: https://doi.org/10.1109/ijcnn.1989.118583

15. Haykin, S. (1994). Neural Networks. A comprehensive foundation. New York: Macmillan, 696.

16. Zhang, B., Muhlenbein, H. (1993). Evolving optimal neural networks using genetic algorithms with Occam's razor. Complex systems, 7 (3), 199-220.

17. Goldberg, D. E. (1989). Genetic Algorithms in Search, Optimization, and Machine Learning. Massachusetts, 432.

Senko Anton, Assistant, Department of Computer Systems and Networks, Kryvyi Rih National University, Ukraine, ORCID: http:// orcid.org/0000-0002-4104-8372,e-mail: antonysenko@gmail.com

Kupin Andrey, Doctor of Technical Sciences, Professor, Head of Department of Computer Systems and Networks, Kryvyi Rih National University, Ukraine, ORCID: http://orcid.org/0000-0001-7569-1721, e-mail: kupin.andrew@gmail.com

Mysko Bohdan, Postgraduate Student, Department of Computer Systems and Networks, Kryvyi Rih National University, Ukraine, ORCID: http://orcid.org/0000-0002-2801-3052, e-mail: b.misko@outlook.com 